International Journal of Art and Art History

December 2014, Vol. 2, No. 2, pp. 01-33

ISSN: 2374-2321 (Print), 2374-233X (Online)

Copyright (C) The Author(s). 2014. All Rights Reserved.

Published by American Research Institute for Policy Development

DOI: $10.15640 /$ ijaah.v2n2a1

URL: http://dx.doi.org/10.15640/ ijaah.v2n2a1

\title{
A Cognitive Interpretation of Aristotle's Concepts of Catharsis and Tragic Pleasure
}

\author{
Mahesh Ananth*
}

\begin{abstract}
Jonathan Lear argues that the established purgation, purification, and cognitive stimulation interpretations of Aristotle's concepts of catharsis and tragic pleasure are off the mark. In response, Lear defends an anti-cognitivist account, arguing that it is the pleasure associated with imaginatively "living life to the full" and yet hazarding nothing of importance that captures Aristotle's understanding of catharsis and tragic pleasure. This analysis reveals that Aristotle's account of imagination in conjunction with his understanding of both specific intellectual virtues and rational emotions of an educated citizen not only tells against Lear's anti-cognitivist construal, but also divulges an alternative cognitive stimulation reading.
\end{abstract}

Keywords: catharsis, tragic pleasure, imagination, judgment, pity, and fear

\section{Introduction}

At Poetics I.6, 1449b25-29, Aristotle articulates the definition of the essence of tragedy that includes its function. ${ }^{1}$ He states:

Tragedy, then, is an imitation [ $\mu i \mu \eta \sigma \iota s]$ of serious and complete action, which possesses magnitude, by being pleasurably embellished through speech with each of the forms separately [employed] in the parts, [through] acting and not through a narrative, by bringing to fruition through pity and fear the catharsis $[x \dot{\alpha} \theta \alpha \varrho \sigma \iota \nu]$ of such kinds of emotions. ${ }^{2}$

\footnotetext{
${ }^{*}$ Department of Philosophy, Indiana University South Bend, South Bend, Indiana, USA.

E-mail: mananth@iusb.edu
} 
Then, Aristotle proceeds to sharpen his point about catharsis in terms of the pleasure qua tragic pleasure that ought to be elicited from the audience:

And the [poet], who produces not the fearful [effect] through spectacle but only the startling-sensationalism [effect], shares nothing in common with tragedy; for it is not necessary to seek every pleasure by means of tragedy but [to seek] the appropriate kind [of pleasure]. And since it is necessary for the poet to produce the pleasure from pity and fear through imitation, it is clear that this [kind of tragic pleasure] must be created within the circumstances [of a tragedy]. ${ }^{3}$

Closely related to the above quotations, Aristotle goes on to describe in which contexts and circumstances pity and fear should be presented:

And whenever misfortunes have occurred among family relationships, for example either [between] brother [and] brother or son [and] father or mother [and] son or son [and] mother, either when one kills [a person] or when one is about to do a thing of such a kind to another [person], one must seek out these [things]. ${ }^{4}$

It is evident from the first of the above passages that the ability to effect a "catharsis" in the individuals of an audience is one of the crucial requirements of a well-constructed tragedy, according to Aristotle. Moreover, the second passage makes clear that the cathartic effect of a tragedy will produce an "appropriate pleasure" of a certain kind. Lastly, the third passage above indicates that the appropriate method of bringing about the emotions of pity and fear (and the corresponding kind of "tragic pleasure") is through a certain depiction of the relationships between friends and relatives. Unfortunately, the remains of Aristotle's Poetics (or any of his other works) reveal no thorough account of his concept of catharsis. This dearth of details has resulted in a plethora of interpretations of Aristotle's concept of catharsis. Today, three broad interpretations of these different versions of tragic catharsis have emerged from the research. ${ }^{5}$ Tragic catharsis has been interpreted as a process of either (or some combination of) (1) purgation, (2) purification, or (3) cognitive stimulation. 


\section{Three Interpretations of Catharsis and Tragic Pleasure}

On the purgation view of tragic catharsis, observing a tragedy can assist in removing unhealthy emotions or pathological conditions. Specifically, it is the emotions of pity and fear that are purged. By way of the medical-homeopathic analogy, pity and fear are used to remove pity-and-fear-type emotions and related pathological states in much the same way that illness-causing agents can be removed from a physically ill person by micro-doses of the same illness-causing agents. From this perspective, scholars argue that Aristotle held the view that tragic catharsis is the removal of unhealthy emotional and pathological states and tragic pleasure is the psychological relief or renewal brought about by the removal of such emotions. ${ }^{6}$ Meager promotes the purgation reading of catharsis and tragic pleasure since he thinks that Aristotle's view about the imitation of action "must move us, deeply and consciously, to an intensity of pity and fear which mounts to an emotional climax in us, permitting a sudden and controlled release from tension and restoration of a state of emotional freshness and readiness."7

In contrast to the purgation account, some scholars insist on a purification interpretation. According to this reading, tragic catharsis is the cleansing of the emotions of pity and fear such that the emotions of pity and fear are modified. Tragic pleasure, then, is the enjoyment of the cleansed emotions of pity and fear. So, when the audience comes to understand the honest mistakes made by Oedipus, the audience expresses both pity and fear in the right way and toward the appropriate set of circumstances. In this way, the confusion and pain that frequently accompany pity and fear are cleansed away by the focus of those emotions on a fully comprehensible set of tragic events (e.g., Oedipus). Butcher states the purification view (as a response to the purgation interpretation) by noting that tragedy provides "an outlet for pity and fear, but to provide for them a distinctively aesthetic satisfaction, to purify and clarify them by passing them through the medium of art." 8

Distinct from both the purgation and purification renderings is the cognitive stimulation / clarification interpretation of catharsis and tragic pleasure. According to this approach, Aristotle takes the cathartic experience to be that of improved understanding of the details of both a particular plot and the actions of the actors. Additionally, the universal aspects of the human condition are better understood by 
the unfolding of the pitiable and fearful events of a tragedy. Golden stands as one of the prominent defenders of this construal. He thinks that catharsis and tragic pleasure are best understood in terms of inferences made by the observer of a tragedy. Such inferences reflect cognitive clarification in the sense that they provide a better understanding "of the individual act by providing, through the medium of art, the means of ascending from the particular event witnessed to an understanding of its universal nature, and thus permits us to understand the individual act more clearly and distinctly." "On this cognitive stimulation/clarification reading, then, catharsis is the process by which observers of a tragedy are better able to realize the nature of particular actions of a protagonist and human actions more generally. Tragic pleasure, moreover, is the accompanying cognitive pleasure of this better understanding, which is illuminated by pitiable and fearful events. ${ }^{10}$

\section{Lear's Challenge}

In a number of places, Jonathan Lear has argued that none of the above interpretations can be defended on the basis of Aristotle's corpus. ${ }^{11}$ This essay, in part, will focus on Lear's rejection of catharsis as a process of (3) cognitive stimulation. Basically, Lear provides what he calls an "anticognitivist" interpretation of catharsis, an interpretation which he considers to approximate most closely what Aristotle's own account would have been. Lear's view is summed up in the following two passages:

1. For an anticognitivist like myself does not believe that there is no role for cognition and its attendant pleasure in the appreciation of a tragedy; he only denies that cognitive pleasure is to be identified with tragic pleasure. For the anticognitivist, cognitive pleasure is a step that occurs en route to the production of the proper pleasure of tragedy. ${ }^{12}$

2. Tragic poetry provides an arena in which one can imaginatively experience the tragic emotions: the performance of a play "captures our souls." However, it is crucial to the pleasure we derive from tragedy, that we never lose sight of the fact that we are an audience, enjoying a work of art. Otherwise the pleasurable katharsis of pity and fear would collapse into merely painful experience of those emotions. Aristotle is keenly aware of the important difference between a mimesis of a serious action and the serious action of 
which it is a mimesis. The emotional response which is appropriate to a mimesis - tragic pleasure and Katharsis - would be thoroughly inappropriate to the real event. ${ }^{13}$

Lear stresses that the cognitive element and its associated pleasure in a cathartic experience are merely "causal antecedents of the proper effect and proper pleasure of tragedy."14 According to Lear, the proper pleasure of tragedy is the joy we experience when "[w]e imaginatively live life to the full, but we risk nothing.",

In response, this essay reveals that Lear's thesis can be weakened to the extent that it is reasonable to think that Aristotle thought that tragic catharsis is associated with the pleasure of judging fairly and sympathetically the actions of the characters in a tragedy. Additionally, given Lear's use of imagination, this essay will also reveal that, for Aristotle, the imaginative faculty has a cognitive dimension that is constitutive of various sorts of pleasure, including tragic pleasure. If correct, then this cognitive aspect of the imaginative faculty further casts doubt on Lear's account of how Aristotle likely understood catharsis and tragic pleasure. If this overall positive account is reasonable, then locating Aristotle within the cognitivist camp is also reasonable.

\section{Citizenship and Judgment: Catharsis and Tragic Pleasure}

The positive account to be proposed provides a credible interpretation of catharsis that will reveal the implausibility both of Lear's two points and of his anticognitivist account of catharsis in general. Even granting Lear his strategy of using the Politics as a means of understanding tragic catharsis in the Poetics, the positive account to follow will still undermine his argument. By synthesizing aspects of Aristotle's Politics, Poetics, Nicomachean Ethics, De Anima, Rhetoric, and Sophocles's Oedipus the King, a plausible approximation of Aristotle's response to the challenge presented by Plato can be put forth. ${ }^{16}$

To begin, it is important to introduce a distinction that has been often neglected in the current literature on catharsis: the distinction between the kind of cathartic experience that the citizenry of the polis has and the kind of cathartic experience restricted to all other denizens. The Politics alludes to just this division in which Aristotle discusses the role attributed to music: 
[It is necessary] for everyone that a certain catharsis [ $\tau \iota \nu \alpha x \dot{\alpha} \theta \alpha \varrho \sigma \iota \nu]$ is brought about and [it is necessary for everyone] to be satisfied in the midst of pleasure. And similarly, the effective melodies also render a harmless gratification to humans. $^{17}$

On which account, the participants, when they perform theatrical music, should be permitted to use harmonies of these kinds and melodies of these kinds; but since the spectator is two-fold: one group is free and has been educated, while the other group is vulgar and is grouped together from workings and hired laborings and other things of such kinds, one must provide contests and spectacles and things of these kinds with a view to relaxation... and what is suitable according to nature provides pleasure for each. $^{18}$

These passages from Aristotle reveal the following argument he is making with regard to class and catharsis. Basically, within the context of his best or ideal city-state, he is claiming that the having of a cognitively based cathartic experience requires individuals who are naturally free (have leisure) and educated. In contrast, the having of emotional excitation, or hedonistic frenzy alone, is relegated to individuals who are naturally vulgar and uneducated. Therefore, since citizens have the requisite leisure and education and workers and slaves lack both, citizens of the polis naturally do have cognitively based cathartic experiences, and workers and slaves naturally only have emotional or hedonistic cathartic experiences. ${ }^{19}$ The purpose of laying out this argument is to impress upon the reader Aristotle's own division between the kinds of aesthetic experience had by non-citizens and citizens. This distinction will prove most valuable as my argument unfolds.

That a tragedy even more than music is included in the above argument will now be examined. The discussion can commence with Aristotle's account of a properly formed plot in a tragedy. The plot and representation of character are the most important aspects of an Aristotelian tragedy (although the rest are necessary to achieve the full theatrical effect) because of their connection with action. It is action (within the construction of the story), which establishes the character of the protagonist, that the audience is being asked to judge. The point about judgment is clear in the Politics, where Aristotle emphasizes the importance of "judging correctly 


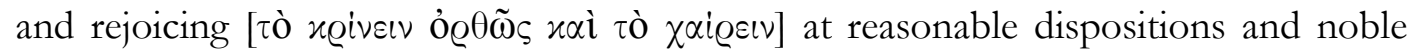
actions." 20 This emphasis on action, moreover, is clearly articulated in the Poetics:

For tragedy is an imitation not about people but about actions and life, and both happiness and unhappiness are in action, and the end is a certain kind of action, not a quality. And it is according to character that people have certain qualities, but they are happy or the opposite according to their actions.

Therefore, they [i.e., the poets] do not act in so far as to represent character, but they include character for the sake of actions; consequently, the events and the plot are the goal of a tragedy, and the goal is the most important of all [the elements of a tragedy]. ${ }^{21}$

Aristotle does not mean just any type of action, however, in his discussion of tragedy. He is referring to a change from happiness to misfortune that is the result of a mistake $[\dot{\alpha} \mu \alpha \varrho \tau i \alpha]$ made by a person of good character (e.g., Oedipus). ${ }^{22}$ This distinction between action and tragic action is crucial to Aristotle's system. One kind of action that he does not allow in a tragedy is that of base or guilty people whose actions are intentionally criminal. These people, due to their baseness, do not warrant our pity when bad things happen to them. Aristotle also does not allow the depiction of fortunate events that befall virtuous people, because there is no choice made by these virtuous people that can be judged in such circumstances. Rather, he includes the representation of the unfortunate actions of virtuous people whose actions are based on their deliberative choices [

It is the deliberative choices of people in a tragedy, then, that the audience judges. In order to understand to what this kind of judging amounts, it will be necessary to explicate Aristotle's two practical virtues concerned with conduct in Nicomachean Ethics, VI.9-11, and then turn to how they relate to the specifics of tragedy. The two practical intellectual virtues that are to be distinguished here are

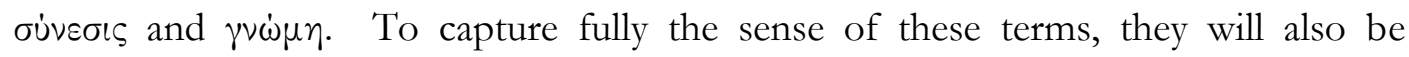
distinguished as subordinate virtues in relation to the superlative practical virtue of

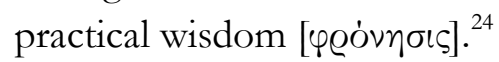

According to Aristotle, an individual who acquires practical wisdom has the ability to judge and determine correctly the truth or falsity of moral judgments (his 
own moral judgments as well as others). Further, this morally insightful man has the unique characteristic of never erring in such judgments. It is the combination of these two characteristics that reveals why Aristotle understands a man who has acquired the rather elusive intellectual virtue of practical wisdom to be a rather exceptional person. Thus, Aristotle expresses the possession of practical wisdom as "the state of the soul by which we always grasp the truth and never make mistakes, about what can or cannot be otherwise." 25 By taking all of this together, it is should be clear why most scholars correctly understand $\varphi$ Qóvnoıs as practical wisdom.

As Louden stresses, both $\sigma \dot{v} v \varepsilon \sigma \iota \varsigma$ and $\gamma \nu \dot{\omega} \mu \eta$ are subordinate virtues with respect to practical wisdom. ${ }^{26}$ That is, a man who possesses practical wisdom is

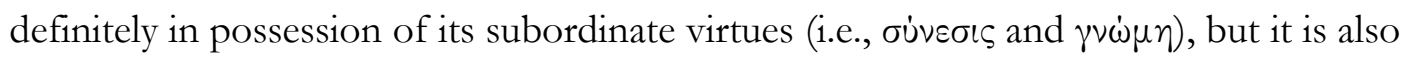
possible for a man to be in possession of one or both of the subordinate virtues and still not acquire practical wisdom. The justification is that, because it is a prescriptive virtue that enables us to know what to do, practical wisdom is concerned with both universals and particulars. ${ }^{27} \quad \sum \dot{v} v \varepsilon \sigma \iota \varsigma$ and $\gamma \nu \dot{\omega} \mu \eta$, while concerned with critically

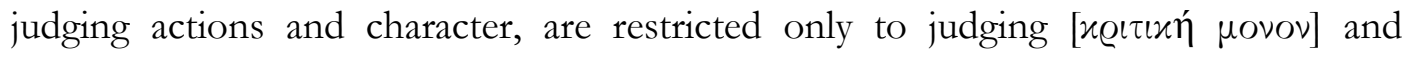
grasping particulars. ${ }^{28}$

Keeping these intellectual virtues in mind, the ability to reflect critically and judge the mistakes of others within the context of a tragic plot is the primary issue at hand here. For Aristotle, the honest mistake would be the only kind of action that would effectively produce pity and fear, because the actions of a corrupt person would shock us rather than move us in the direction of pity and fear. Similarly, the good fortune of accidental events of the virtuous man's actions is not convincing but absurd because it is not in conformity with necessity or probability. A $\mu \alpha \varrho \tau i \alpha$ is to be understood, then, as an error or mistake made by a protagonist in a tragedy due to his ignorance of particulars. ${ }^{29}$ This definition of error in tragic plots is categorically concluded by Aristotle in the Poetics:

Consequently, it is necessary for the plot that is well-made to be single rather than double, as some say, and change [occurs] not from misfortune into good fortune, but the opposite: from good fortune into bad fortune, not through wickedness, but through a great error [ $\dot{\alpha} \mu \alpha \varrho \tau i \alpha \nu \mu \varepsilon \gamma \alpha \dot{\alpha} \eta \nu]$ either just like I have stated or better rather than worse. ${ }^{30}$ 


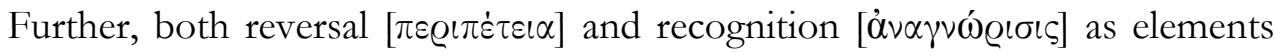
of a well-constructed plot aid in amplifying the probability and/or necessity of such honest mistakes - the former by exemplifying the antithesis of the expected results of particular actions (i.e., unintended consequences), and the latter by bringing about a state of knowledge from a state of ignorance. According to Aristotle, the best plot will have recognition and reversal occurring simultaneously, as in Oedipus The King. ${ }^{31}$ The cathartic experience, then, will reach its apex when this marriage between reversal and recognition occurs because both pity and fear will accompany these elements of the tragedy.

Here we see a very powerful strategy employed by Aristotle in his attempt to produce the emotions of pity and fear in the audience, emotions that will aid in their ability to adjudicate equitably the character of the protagonist. For example, when a messenger arrives to tell King Oedipus that his father in Corinth has recently died from natural causes, there is a tremendous feeling of relief on the part of Oedipus (and the audience) that he was not the cause of his father's death as the prophecy warned. Unfortunately, two other messengers arrive to reveal that the King in Corinth was not Oedipus's real father and that he had been delivered to the King of Corinth at his birth. Oedipus's reaction is that of horror and stupefaction. This reversal of events, along with the amazement expressed by the two messengers who recognize each other after many years, provide the missing information that reveals the error in Oedipus's actions.

As noted earlier, Aristotle places such a strong emphasis on this definition of a mistake within the context of a complex plot because he does not wish it to be confused with deliberate wrong-doing. For example, Oedipus's accidental killing of his father and subsequent marriage to his mother represent the kind of nondeliberative mistake that Aristotle is stressing. The issue is that Aristotle is concerned with the difficulties that arise out of complex interactions between a person of good character and other friends and family in his environment. Since an individual's character is best analyzed by those closest to him, it is crucial for friends and family to cultivate and employ the skills of ethical judgment.

Aristotle's point is that the cathartic experience is not merely the result of treating a tragedy as a didactic exercise upon which one reflects in isolation, but must be an activity that includes close friends and family. ${ }^{32}$ Friendship and filial relations 
provide the kind of interaction appropriate for improving one's character, as noted above. Observing a tragedy is an activity that allows friendship among family and neighbors to "become better as they are active together and correct one another: from the mold of each he takes the imprint of the traits he likes, whence the saying: 'Noble things from noble people'.",33

Oedipus the King is the appropriate exemplar of the above discussion. Oedipus is a man of good character and virtue but is still the victim of terrible circumstances that are beyond the deliberative choices he makes. True friendship (which is an important element of one's moral character) is the ability tactfully to see past such misfortunes or mistakes and assess the correct character of one's friend in the light of how he has deliberated on his actions. ${ }^{34}$ Aristotle's discussion of the requirements for tragic character in the Poetics and character in the NE specifies the relationship between an individual's character and his actions, speech, and decisions:

And [tragedy] will have character if, just as we said, the speech or the action makes apparent a deliberate choice of whatever sort; [and it will have] upright [character], if [it makes apparent] an upright [deliberate choice]. ${ }^{35}$

Indeed, since we wish for the end, and because we also wish and deliberately choose things with a view to the end, the actions concerning these things would be according to deliberate choice and voluntary. And the activities of the virtues are concerned with these things. Indeed, virtue is also up to us, and similarly also vice. ${ }^{36}$

The above quotations reveal that the actions and words of individuals generally, as well as in a tragedy, divulge their decisions and character. But how does this relationship between actions and character relate to catharsis and cognition? Keeping in mind the earlier discussion of Aristotle's intellectual virtues, a turn to what can be considered a strong connection between catharsis and cognitive stimulation is in order.

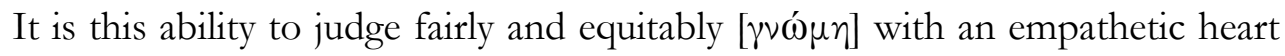

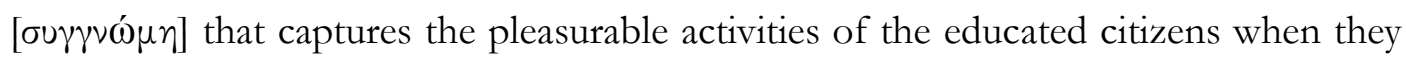
observe a tragedy in Aristotle's system, or so it shall be argued. To elaborate, the cathartic experience (that is the representations) produces the feelings of pity and fear 
which concomitantly evoke emotions of sympathy from the audience (with regard to the actions of the protagonist) and feelings of dread that such errors could conceivably be committed by themselves. Only the citizens of the polis have the virtues of $\sigma \dot{v} \varepsilon \varepsilon \_\varsigma$ and $\gamma \nu \dot{\omega} \mu \eta$ to evaluate critically and correctly actions of the protagonist and focus appropriate attention on his intentions in relation to the given circumstances after the initial emotions of pity and fear are experienced. Reasonably, in contrast to Lear's position, the proper effect of a cathartic experience via tragedy can be the cognitive pleasures produced from the activities of judging equitably and empathetically.

A final look at Sophocles's Oedipus the King may help to synthesize what can be considered to be Aristotle's approach to the cathartic experience. The story begins with Oedipus hastily deciding to leave his parents in Corinth due to the prophecy by Phoebus (that Oedipus would kill his father and sleep with his mother) that was prompted by a drunkard at a dinner party. As the story unfolds, Oedipus establishes a new life as the King of Thebes only to find out that the woman he has married and who is the mother of his children, Jocasta, is also his mother who abandoned him as a baby. To make matters worse, Oedipus discovers that one of the men whom he killed on the road during his initial departure from Corinth was his wife's husbandOedipus's real (biological) father! As a result of these unbearable events Oedipus violently blinds himself.

The citizens of the polis, it has been argued, not only have the ability to

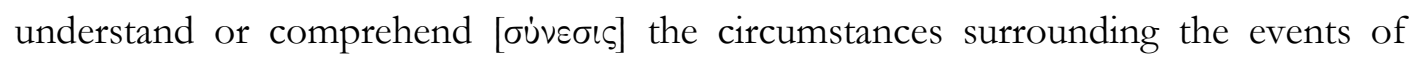
Oedipus the King, but they also have the good sense to judge Oedipus fairly/equitably

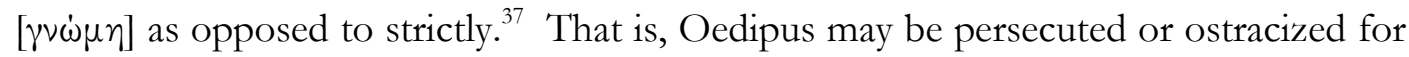
the killing of the men during his flight from Corinth (admittedly, Oedipus was defending himself, but it is possible that he could have "negotiated" a less violent means of resolving the conflict), but he would not be condemned for patricide or incest because those actions were based on a mistake or error. Oedipus's character can, for the most part, be judged based on actions that were the result of deliberate choice. $^{38}$ The audience is moved to this decision because the cathartic effect, which is achieved through pity and fear, produces such a response.

From this perspective, only some citizens of the polis, for example, have the

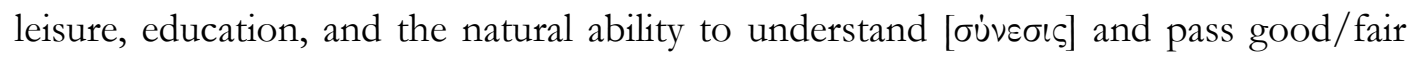


judgments $[\gamma \nu \dot{\omega} \mu \eta]$ on the errors (ignorance of particulars) made by the characters in tragic plays. Most importantly, citizens are also able to connect relationships of various actions, which can have an impact on anyone anywhere (universals) "in accordance with probability and necessity." "39 The ability to make such connections is the extended cognitive stimulation that reversal, recognition, and suffering, which contain pity and fear, can produce in some of the citizenry who have these mental aptitudes and moral virtues.

The workers and slaves, conversely, do not have the education, leisure (freedom), or the mental faculties to recognize moral virtue. Thus, they are unable to make equitable judgments regarding which actions determine or do not determine an individual's character. As noted earlier, the result is that they are restricted to musical contests, the initial emotional jolt of a tragic play, or the impulsive frenzy of a religious ritual. Again, the Politics reveals just this special distinction between liberated citizens and all others in the polis: "a virtue that belongs to a citizen must not be spoken of all (citizens), and not even of a free citizen only, but (only) to as many as those who are liberated from necessary working-occupations that are difficult." 40

In summary, although the impact of tragedy (or art in general) would vary from the citizenry to all others within the polis, everyone receives some level of satisfaction and/or intellectual stimulation. Both non-citizens and citizens, on the one hand, are entertained and are able to relax from the rigors of daily life. Only some citizens, on the other hand, have the individual satisfaction of attempting to resolve difficulties that are outside the scope (an adjournment) of everyday problem solving, but that can be the foundation of daily interaction.

\section{Catharsis and Tragic Pleasure in the Light of Imagination}

If this version of how Aristotle understood the cathartic experience is correct, then it tells against Lear's view on how to understand Aristotle as a respondent to Plato. First, if the peculiar pleasure of catharsis (for citizens of the polis) involves the

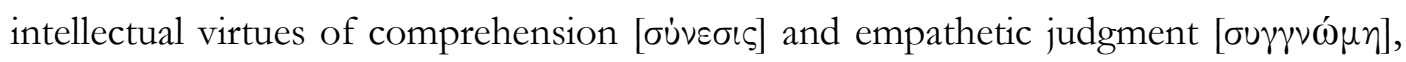
then such an experience is deeply tied to the rational part of the soul. The consequence is that Aristotle can now be viewed to be providing a reply to Plato that poetry can enhance the rational part of the soul through the skills of comprehending and judging empathetically. Therefore, if this interpretation is a reasonable 
approximation of Aristotle's account of catharsis, then Lear's belief that Aristotle defended the idea that the cathartic experience is neutral with respect to its influence on the rational part of the soul is mistaken.

Furthermore, Lear's claim that the cognitive element is nothing more than a precondition of tragic pleasure is also open to objection. There are two ways to respond to this claim. First, if the positive account of the cathartic experience in the previous section is correct, then the pleasure that attends judging empathetically is a rational pleasure. As a result, the cognitive element of the cathartic experience is no longer a causal antecedent to the proper pleasure of poetry (as Lear thinks), but is constitutive of the pleasure that attends the cathartic experience.

Lear could reply, however, that this analysis ignores the imaginative element $[\varphi \alpha \nu \tau \alpha \sigma i \alpha]$ that is a needed part of Aristotle's account of catharsis. Recall, Lear thinks that an integral part of the cathartic experience is that "[w]e imaginatively live life to the full, but we risk nothing." The assumption of this kind of response, of course, is that the psychology of imagining, for Aristotle, is necessarily minimally cognitive and harmless with respect to the soul. Yet, Baxter correctly points out that Lear's analysis depends "crucially on an appeal to 'imagination"." Moreover, hinting that Lear has not explored the details of such an appeal, Baxter stresses that "more work needs to be done to illuminate the connection between mimesis and imagination." 41 This section and the next forge just such a connection suggested by Baxter.

The problem with Lear's use of imagination is two-fold. First, Aristotle's account, as interpreted by Lear, would fail to meet Plato's objection. Plato would reply that Lear's notion of imagining a sensible object is the production of a representation that is thrice removed from The Forms. Lear's account could not be utilized in this way by Aristotle to explain the cathartic experience. Plato would have rejected it straightaway because of its soul-harming effects.

Second, it is not at all clear that Lear is entitled to offer the above objection, because it is not clear that Aristotle recognizes the sense of imagination that Lear uses. To see this, a review of Aristotle's account of the faculty of imagination, that is $\varphi \alpha \nu \tau \alpha \sigma i \dot{\alpha}$, is in order. After making clear that his predecessors accounts of the soul are wanting due (in part) to their inability to allow for the failure of the content of mental states to correspond with the way the world is (i.e., "mental error"), Aristotle 
introduces imagination to fill the lacuna. ${ }^{42}$ Furthermore, before offering his considered view on the nature of imagination, Aristotle makes clear that, even granting that the faculty of imagination is related to either perception or reason, it is not identical to (1) sensation (perception), (2) conception, (3) knowledge, (4) belief, and (5) a combination of belief and sensation. The implication is that the faculty of imagination is (in some sense) a distinct mental faculty.

Aristotle begins his account of imagination by suggesting how it is related to sensation. He then proceeds to locate where imagination does not admit of error and where it does admit of error. Additionally, he turns to differentiate senses of imagination with respect to humans and all other animals, making clear that animals

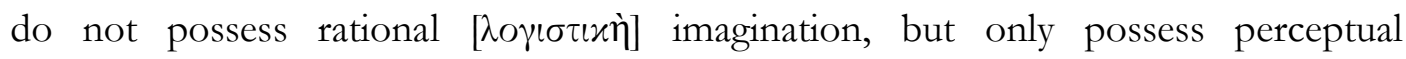

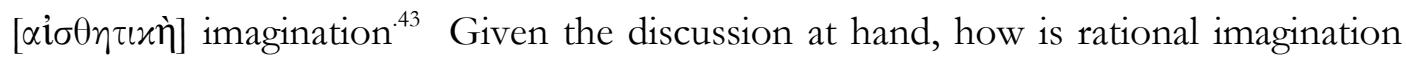
in humans to be understood?

Scholars dispute how to make sense of Aristotle's answer to the above question. Some argue that rational imagination is nothing more than a necessary condition for reason qua calculation, ${ }^{44}$ while others insist that it can function much like reasoning. ${ }^{45}$ One way of understanding this debate is to determine where rational imagination should be located on the spectrum between perception and thinking; the former (at one extreme) being non/minimally cognitive and the latter (at the other extreme) being maximally cognitive:

Sense Perception (non/minimally cognitive)...??«rational imagination»??... Thinking (maximally cognitive)

To start, Aristotle categorically states that rational imagination is a faculty of discrimination:

Now we see that the things which move the animal are intellect, imagination, purpose, wish, and appetite. Now all these can be referred to mind and

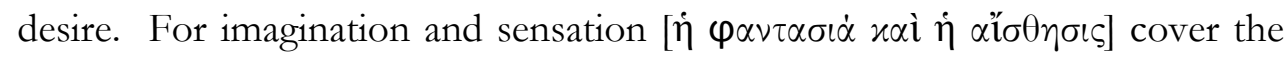
same ground as the mind, since they all exercise discrimination [ $\left.\iota_{\imath} \iota x \grave{\alpha}\right]$, though they differ in certain aspects as has been said elsewhere. ${ }^{46}$

Aristotle makes clear in the above passage that the faculty of imagination engages in discrimination. Yet, in this context, discrimination ranges over both 
imagination and sensation. This suggests that imagination takes on more of a minimally cognitive role much like the role perception plays in human and nonhuman animals. Still, Aristotle is quick to point out that they differ in certain ways. What this means is that, although both perception and imagination discriminate, they do not do so in precisely the same manner. Can imagination perform in a more robust cognitive way in the case of humans? Well, to plumb a bit further, as part of his account of how movement occurs, at De Anima, 433b29-30, Aristotle notes (as mentioned above) that all imagination is related to either reason or sensation. Very soon after this passage, at 434a7-8, he says that the calculating faculty of imagination is only found in those organisms that possess the reasoning ability. Notice that, in his description of the calculating sense of imagination, Aristotle shifts from rational to deliberative in order to render a precise sense of rational; for he goes on to explain the deliberative sense of rational imagination as it relates to practical reasoning. He tells us:

So, perceptual imagination, just as it has been said, is present in other animals,

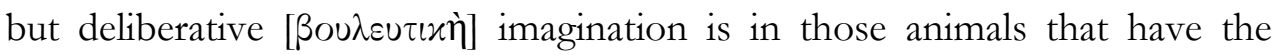
reasoning ability. For whether this or that shall be enacted is already a result of the work of reason; and it is of necessity to measure in one way; for one seeks after the greater [of two options]; it follows that what acts in this way must be able to make a unity out of several images. ${ }^{47}$

As is made clear in the above passage, the sense of rational imagination is deliberative imagination as it is tied to practical reasoning. One reasons qua calculates about which option (amongst competing options) is best able to achieve a particular end. Yet, in order for the reasoning faculty to be able to do this, it must have a number of available options from which to choose. Although the presence of these options is itself the work of imagination and reason, each option is a composite of $\mathrm{x}$ number of images. The reasonable inference, then, is that deliberative imagination has the function of synthesizing together various images to create a composite image.

Moreover, why is the presence of such options already a result of the work of reason? Aristotle does not explicitly give an answer, but the reasonable one is that the ability to form a number of composite images, which reason uses as options in the light of the end under pursuit, is a rational activity. Specifically, deliberative imagination "calls up" and forms the relevant images (from a range of many) in the 
light of the end under consideration and then synthesizes the relevant images into image-options in a way that allows for reason to convert the image-options into the various means that will assist in the achievement of a particular end. ${ }^{48}$ Then, reason will calculate which option best assists in securing the target end. Thus, deliberative imagination is a rational faculty in the sense that it (1) makes manifest a range of images with respect to the end being pursued and (2) synthesizes the relevant images into unified sets of image-options so that practical reason can perform its function. On this interpretation, then, deliberative imagination is both an image selector/producer and an image synthesizer.

Now, recall that Aristotle also thinks of deliberative imagination as discriminating or discerning. Not only is deliberative imagination able to discern in the fashion noted above, but it is also able to unify images concerning possible future events. Aristotle makes this point within the context of practical reasoning:

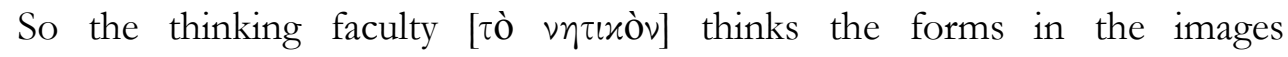
$[\varphi \alpha \nu \tau \dot{\alpha} \sigma \mu \alpha \sigma l]$, and just as in those cases what was to be pursued and avoided is determined for it, so also beyond perception, whenever it is directed towards images, it is moved, as for example someone seeing a beacon sees that it is a fire, and seeing it moving knows that it is hostile; but sometimes also it

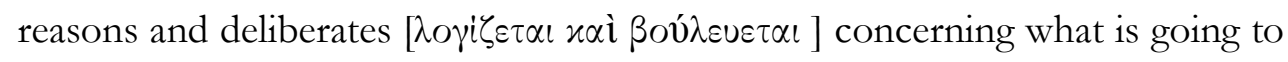
happen by means of images or thoughts in the soul on the basis of what is present. $^{49}$

In part, the above account suggests that the ability to produce mental images about future events is the work of the thinking faculty by way of both images $[\varphi \alpha \nu \tau \dot{\alpha} \sigma \mu \alpha \tau \alpha]$ and thoughts in the soul. This can be interpreted in at least three ways. One, Aristotle is claiming that imagination by itself can produce mental images about the future for the thinking faculty, which then deliberates and calculates concerning such images. Two, he could mean that imagination and thoughts can independently produce mental images for the thinking faculty. Three, he could mean that the combination of images and thoughts produce mental images of future events upon which the thinking faculty can reflect.

Although there is no knockdown evidence in favor of any of the above accounts, in his discussion of animal movement, Aristotle does hint at interpretation 
one as follows: "that which moves would be one in form, that is the appetitive faculty qua appetitive, but the thing desired would be the first of all things (for this brings

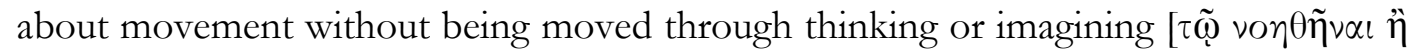
$\varphi \alpha \nu \tau \alpha \sigma \theta \tilde{\eta} \nu \alpha \imath]^{50} \quad$ Here, Aristotle explicitly acknowledges (by way of 'or') that imagination is able independently to access desired objects. Smith translates this passage to include "being apprehended in thought or imagination." 51 Although 'apprehended' is not explicitly stated by Aristotle, there is scope for this interpretation here.

The crucial assumption here is that 'apprehend' must be interpreted as a capability both (1) to discriminate that an object is an object of a certain sort and (2) to construct a future image of said object. We have already seen that (1) is clearly defended by Aristotle. Interestingly, in his Rhetoric, Aristotle acknowledges (2). Within the context of distinguishing between fear and confidence, he says:

Confidence is both the opposite with respect to fear, and [what brings about] confidence [is the opposite of what brings about] fear; thus it is in concert with the imaginative expectation [ $\varphi \alpha \nu \tau \alpha \sigma i \alpha \varsigma \dot{\eta} \dot{\varepsilon} \lambda \pi \dot{i} \varsigma]$ of things that are safe [that they are also the things] that are nearby, while the things that are fearful either do not exist or are far off. ${ }^{52}$

The passage makes clear that being confident is attached to expectationimages associated with either those things that keep us safe or the remoteness of those things that would put us in harm's way. Clearly, to expect is to have futureoriented images of close things that are good or distant things that are bad. On this view, then, imagination can independently produce images of future images qua expectation-images. Indeed, this is in keeping with Aristotle's beacon of fire example noted above; that is, when one sees such a fire, one forms images of what one anticipates or expects will occur; for example, that one's village will be burned to the ground or that one's army has arrived. Thus, it is reasonable to infer that imagination is able both (1) to discriminate that an object is an object of a certain sort and (2) to construct a future image of said object.

If the above analysis is on the mark, there is no reason why deliberative imagination cannot independently apprehend and construct future object-images of the desired object. For instance, not only does deliberative imagination apprehend that object $\mathrm{X}$ is a dessert, but it is able to construct the future image-object of the 
observer enjoying the dessert at some future time T. Thus, deliberative imagination can independently apprehend an object and can construct, for the thinking faculty, future object-images (this will require synthesis of images as well) of an apprehended object.

In summary, deliberative imagination is a cognitive feature of the rational soul to the extent that it is able to (1) apprehend independently that an object is a certain kind of object, (2) construct future object-images, (3) select images, (4) produce images, and (5) synthesize images. With these characteristics in place, it is clear that not only is deliberative imagination far removed from being minimally cognitive, but can be reasonably understood to be in the highly cognitive range (though not maximally cognitive).

Still, Lear might contend that his analysis remains untouched by my interpretation. He could very well grant this interpretation and claim that all the "intellectual stuff' that has been articulated is a mere antecedent to the actual pleasure of catharsis. To elaborate, whenever someone offers a cognitive account of Aristotle's concept of catharsis, Lear could always grant such an interpretation, but insist that it is merely a causal antecedent to the "real tragic pleasure" associated with catharsis. Such a move, however, should be viewed with much suspicion, because such a reply would render Lear's analysis unfalsifiable. That is, no matter what cognitive account of catharsis is offered, Lear could always claim that such an account is a mere causal antecedent to the proper effect of tragedy. Moreover, if it is the case that Lear's use of imagination is inappropriate, then his use of it as part of his anticognitivist account of the real tragic pleasure of catharsis is weakened as well. Thus, it is reasonable to conclude that Lear's account of Aristotle's reply to Plato's challenge is off the mark.

Moreover, even if it is assumed that deliberative imagination is one of the linchpins to understanding the cathartic experience, it seems to run counter to Lear's anti-cognitivist account. Specifically, deliberative imagination, according to Aristotle, is a highly cognitive activity associated with both moral and non-moral actions. It reasonably follows that its attending pleasures can be of a rational qua cognitive sort. This means that, for Lear, the tragic pleasure produced by catharsis would include (at least in part) cognitive pleasure-an implication that Lear would not wish to countenance. Thus, it does not appear that Lear is in a position to employ, from an 
anti-cognitivist perspective, Aristotle's account of imagination in order to make sense of his concepts of catharsis and tragic pleasure.

\section{Imagination, Pity \& Fear, and the Pleasure of Catharsis}

More must be said about imagination and its relationship to catharsis and tragic pleasure; for Lear is correct to mention imagination, but its exact role with respect to the observance of a tragedy must be made clear. First, attention will be given to how imagination is related to comprehending and judging empathetically the actions of someone like Oedipus and how such comprehending and judging are related both to deliberative and perceptual imagination. Second, the physical and cognitive dimensions of pity and fear will be explained.

Recall that in order for the mind to reflect on the appropriate features of a particular image, deliberative imagination must conjure up the relevant image. The nature of such images qua likenesses is explained by Aristotle as follows:

For just as the animal drawn on a tablet is both an animal and a likeness, and this is both one and the same thing, the essence, however, is not the same for both, and it is possible to think [of the drawing] both as animal and as a likeness, and in this way it is also necessary to accept that the image in us [ $\tau$ ò $\dot{\varepsilon} \nu \dot{\eta} \mu \tilde{i} \nu \varphi \dot{\alpha} \nu \tau \alpha \sigma \mu \alpha]$ is itself essentially [ $\left.\kappa^{\prime} \alpha \theta^{\prime} \alpha \dot{v} \tau \dot{\jmath}\right]$ an object of contemplation and an image $[\varphi \dot{\alpha} \nu \tau \alpha \sigma \mu \alpha]$ of something else. ${ }^{53}$

In the same way that a drawing of an animal can be viewed both as an animal and as a likeness of an animal, the likeness of an animal in our minds is simultaneously both (1) a mere image of an animal that has the shape of an animal and (2) an image qua likeness (conjured up by deliberative imagination) upon which the thinking part of the soul reflects. It is in this sense that the ontological status of the same mental image can be different. In this way, the image of a gouge-eyed Oedipus is both the shape of a man and an image qua likeness of ill-fated Oedipus-an image that is stitched together by deliberative imagination. 
In the Poetics (noted above), Aristotle states that non-philosophers and philosophers "take pleasure when they see likenesses, because while they observe they

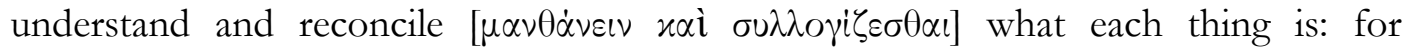
instance, that this [person] is that [person]." ${ }^{54}$ However, he qualifies his claim about

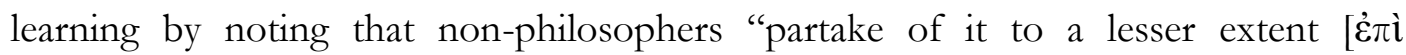
$\beta \varrho \alpha \chi v े] . " 55$

Again, we see Aristotle making a distinction between different sorts of aesthetic experiences - in this case different degrees of cognitive pleasures-had by different members of the polis. Non-philosophers have cognitive pleasures of likenesses to a far less degree than philosophers. Yet, Aristotle's educated citizen stands between these two extreme groups. As I argued earlier, it is the pleasure that accompanies the joy in having judged finely that captures the cathartic experience for these educated citizens. Thus, granting that the education of citizens will vary, it reasonably follows that the less educated citizen shares in this cognitive pleasure to a lesser extent than the more educated citizen and the more educated citizen shares this pleasure to a lesser extent than the highly educated philosopher. For example, (1) responses by the less educated may be more visceral than cognitive, (2) the more educated could glean the pleasures of judging finely, and (3) the philosophically educated would be able to reflect on the metaphysical and ethical dimensions of the universality of poetic expression.

Now, one may still be skeptical of my positive account of catharsis and imagination, even if Lear's analysis is not satisfactory. Specifically, one could reply that the positive account offered here over intellectualizes Aristotle's sense of the cathartic experience. Even if one were to grant that there are different sorts of cathartic experiences amongst citizens and non-citizens, it does not follow that the cathartic experience of the citizenry is so closely tied to judging finely. Such fine judgments may be both appropriate and required for the scientist and the philosopher, but seem out of place for the average citizen of the polis-even Aristotle's ideal polis.

In reply, Aristotle's own assessment of the generally educated man of the polis clearly tells against this skeptical concern:

There appears to be two ways of being in a certain state of understanding, of which one possesses what can rightly be called the scientific understanding of 
the subject matter, and a certain kind [of understanding that can be called] the general-education understanding, concerning both every study and inquiry, and in a similar way for both more humble [studies and inquiries] and more honorable [studies and inquiries]. For it is in keeping with character of the educated man to be able to judge accurately what is fair or what is not fair in an explanation. For, indeed, we also think that the generally educated man [ $\tau$ ov ö $\lambda \omega \varsigma \pi \varepsilon \pi \alpha i \delta \varepsilon u \mu \varepsilon \dot{\varepsilon} \mathrm{\sigma})$ ] is this particular kind [of judging person], and [we think that] being educated is being able to do that which was said. ${ }^{56}$

As Aristotle makes clear in the above passage, the generally educated person does engage in various degrees of intellectual activities, some of which include sorts of judging regarding what is fair and unfair. Although such an educated citizen may not be able to engage in highly abstract or philosophical kinds of analysis, he can still engage everyday activities in a reflective and discriminating fashion. Thus, the average educated citizen can reasonably have the sort of cathartic experience I have suggested. This can be seen by connecting rational imagination and catharsis to pity and fear.

So, we can now ask: what about catharsis and tragic pleasure in terms of pity and fear? A review of Aristotle's account of pity and fear and how these are connected to the story of Oedipus should answer this question. For assistance, Belfiore offers the following account of pity as it relates to Oedipus:

Pity involves wailing and weeping...for pity, like fear, involves involuntary, painful physiological reactions (weeping) that are necessary in some way to the production of aesthetic pleasure... These reactions, however, are not involuntary and automatic...Pity, in Greek thought, is an essentially human emotion, dependent on an awareness of the common human lot...we often feel pity for people in completely hopeless situations... We weep while viewing Oedipus with his eyes put out because we see what appears to us to be a man in pain and weeping...Finally, because we shudder and weep at the tragedy qua people weeping, we realise that it is an imitation of a pitiable and fearful event: that this plot is an imitation of that event. ${ }^{57}$

Belfiore notes both the physical and cognitive dimensions to pity with emphasis given to the context of observing a tragedy. Basically, initial weeping of the depiction of a tragic event is a natural physiological response of pity. Then, according 
to Belfiore, the cognitive aspect to pity is that we are able to recognize that the unfolding plot is a copy qua imitation of a real human scenario that involves pitiable and fearful events.

Moving beyond Belfiore, this response of pity becomes both emotionally and cognitively heightened (possibly to the extent of wailing) when one recognizes that near-inevitable events, like those that befall Oedipus, are part of the human condition. This human condition, moreover, is pitied to the extent that, not only do we feel badly for the protagonist's plight, but we also understand that we could find ourselves in reasonably somewhat similar near-inextricable circumstances. ${ }^{58}$ Aristotle makes all of this explicitly clear: "People also pity those who are similar to them in terms of age, in terms of character, in terms habits, in terms of social position, [and] in terms of descent; for in all such [similarities] it appears more likely that [what happens to others] may also befall oneself." 59

On this reading, the cognitive response to an Oedipus-type tale is more than the recognition that this plot is an imitation of that event. Indeed, this understanding

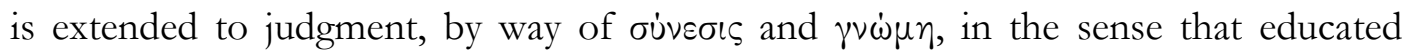
citizens are able to judge empathetically and equitably Oedipus' actions in the light of their own past similar experiences or that they could very well find themselves in similar circumstances-this Oedipus scenario is similar to that event that befell me and, moreover, this Oedipus scenario is a kind of unfortunate happenstance that could very well befall me. This is the cognitive pleasure achieved upon both the empathetic feeling of pity aroused by Oedipus' plight and the corresponding empathetic and fairness judgments. As defended earlier, we take joy in having judged finely. It is at the empathetic judging stage, concomitantly with the recognition that one could be in similar circumstances as the protagonist in a tragedy, from which the heightened cognitive pleasure qua tragic pleasure emerges. ${ }^{60}$

The other element of the cathartic experience is associated with fear. Clearly, the spectacle of terror produces the physiological response of fear, which can have an accompanying feeling of fleeing the object of fear or a kind of almost dreadfulparalysis. ${ }^{61}$ Aristotle explains the physiology of fear as follows: "Then let fear [be understood as] a certain suffering $[\lambda \dot{u} \pi \eta \tau \iota \varsigma]$ or commotion because of an image $[\phi \alpha \nu \tau \alpha \sigma i \dot{\alpha} \varsigma]$ of a looming wickedly destructive or sufferable event." ${ }^{62}$ With respect to tragedy, the audience feels such pain or disturbance as they anticipate the unfolding of 
a plot (in part by way of recognition and reversal discussed earlier), which includes both destructive and painful events that are imminent. Oedipus' patricide and incest, all of which culminates in the gouging of his eyes, bring to fruition the specific destructive and painful events that are broadly and fearfully anticipated ("I know something terrible is going to happen now...") by the audience. Aristotle hints at this kind of account, which includes judgment, emotions, and imagination, in De Anima:

And, moreover, when we judge [ $\delta \circ \xi \dot{\alpha} \sigma \omega \mu \varepsilon v]$ that something is either fearful or threatening, we are at once affected by it, and similarly even when [we judge something to be] cheering; but in relation to imagination we are just like spectators [who are observing] fearful or cheering things in a painting. ${ }^{63}$

Aristotle is clear that, upon judging that $\mathrm{X}$ is terrible or frightening, the relevant emotions (in this case fear) are produced. Notice that causal priority is given to judgments over emotions. From this perspective, emotions are distinct from visceral feeling responses or the initial "pain or disturbance" of threatening evil. This suggests that, for Aristotle, emotions themselves are intertwined with cognitive meaning. Interestingly, as part of his reply to Lear, Halliwell stresses the cognitive dimension of Aristotle's account of emotions with respect to pity and fear (drawing on Poetics 4). ${ }^{64}$ To quote at length, here is his assessment:

The complete experience of a tragedy will necessitate the understanding of the work's significant structure of "actions(s) and life" (6.1450a16-17), the ethical characterizations of its agents, the rationale of their expressed thoughts, and so forth. But this cannot be a coldly cerebral process of ratiocination; it is the necessarily evaluative engagement of the mind with imagined human actions and experiences of a deeply serious and, for Aristotle, a justifiably emotion-inducing kind. It is for this reason that Aristotle speaks interchangeably of, on the one hand, the "pitiful" and "fearful" as properties of a tragic plot structure itself and its components (e.g., 9.1452a2-3), but also, on the other, of pity and fear as the appropriate response of the spectator (or reader) who attends to and is absorbed in this structure of events (e.g., 11. 1452a38-39)...So to suggest, as one scholar has, that the cognitive pleasure of tragedy "is a step that occurs en route to the production of the proper pleasure of tragedy," where this pleasure is said to arise from pity and fear through mimesis, is to separate 
elements that we should expect to find fused, given Aristotle's view...that the emotions themselves are cognitively grounded. ${ }^{65}$

Halliwell insightfully points out that (1) pity and fear are an integral part of Aristotle's understanding of a well-crafted plot, (2) the response of pity and fear (through the help of imagination) on the part of the audience is appropriate because it aids in the audience's ability to make reasonable normative/prescriptive claims regarding human actions and life in general, and (3) that it is a mistake to separate (as Lear does) the cognitive and emotional responses by the audience, since (for Aristotle) emotional responses are mediated by the faculty of reason. As part of his reply to Lear's claim that cognitive pleasure is a step in the direction of the proper pleasure of tragedy, Halliwell notes that such an account separates the cognitive and emotional aspects of the proper pleasure of tragedy when, in fact, these should be kept "fused." 66 Thus, taking (1)-(3) yields further support of the claim that emotions, for Aristotle, are intertwined with cognitive meaning. The further upshot is that, contrary to Lear's account, tragic pleasure is robustly cognitive. ${ }^{67}$

In this same chapter, Halliwell offers his own account of how to make sense of Aristotle on tragic pleasure: "Such pleasure...is considered by Aristotle to arise from the exercise of our capacities for both understanding and emotion in the engagement with the fictive possibilities that art dramatizes." 68 He goes on: "In the case of tragedy, Aristotle's whole theory suggests that an audience needs to have sufficient experience of life to understand various kinds of action, intention, and character; to be able to distinguish degrees of innocence, responsibility, and guilt; to know, in an effectively mature way, what merits pity and fear; to have a grasp of human successes and failures, of the relationship between status and character, and so forth." From all of this, Halliwell concludes that the "peculiar pleasure that tragedy affords will thus be of a compound kind ("the pleasure from pity and fear through mimesis')."69

There is very little here with which I disagree. Note that, with respect to my account, Halliwell's analysis is restricted to the citizen class. Within this class, he has captured very well the cognitive dimension of the educated citizen-audience and the kind of general tragic pleasure they will have. My view is in keeping with his, although I give greater emphasis on judging character and the corresponding joy qua pleasure that comes from doing this well_-all within the context of mimetic pity and fear. My 
only concern with Halliwell's account is when he claims that tragedy provides the audience "with imaginative opportunities to rest, refine, extend, and perhaps even question the ideas and values on which such comprehension rests."70 I would resist this reading, because it requires using both 'comprehension' and 'imagination' in ways that can be misleading. Also, Halliwell does not pursue the role of imagination within this framework. This is why I have offered an account of the role played by rational imagination in the cathartic experience.

Still, even granting my rational imagination account of catharsis and tragic pleasure, Aristotle appears to suggest (in the previous quotation above) that real-life emotions are not really present in the same manner as in the case of emotions associated with mental images; that is, the emotion-states that are produced by images and judgments are more akin to those emotions associated with observing art objects. For example, an image of a growling tiger does not produce the same emotional response as a living growling tiger a few feet away. Aristotle must here mean that the intensity of emotion with respect to art objects is less than the intensity of emotions with respect to real-life frightful phenomena. This interpretation is in keeping with his claims about what thinking and imagination can produce. Aristotle says:

And qualitative change is caused by imaginations and sense-perceptions and ideas. For, on the one hand, sense-perceptions are at once a certain kind of qualitative change, while on the other hand, imagination and thinking have the effect of the objects [out in the world]; for in a way, the idea envisioned about [the warm or cold or] the delightful or fearful comes to be the same kind [of effect], much like [the effects] of what the objects [out in the world produce], and therefore [people] shudder and are frightened when they merely think [of scary things]. ${ }^{71}$

Aristotle clearly states that the combination of imagination and thinking has the power of actual things. The subtle shift here to include thinking with imagination is important. Although images of art objects have a far less intensity of emotion than real-life fearful things, the ideas that emerge as a result of both imagination and thinking have potencies much like actual real-life things. As discussed earlier, deliberative imagination constructs the image upon which the thinking faculty reflects. Again, for example, an image of a growling tiger and the thoughts that emerge as a result of thinking about the image of a growling tiger are almost as powerful as a real- 
life growling tiger. As Aristotle puts it, this is why we shudder and are frightenedeven when we are merely thinking of menacing things. This means that the combination of images of $\mathrm{X}$ (which may include deliberative imagination-induced foreboding evil images) and thoughts about images of $\mathrm{X}$ can produce a rather similar kind of fear that emerges from observing real-life fearful things. The major difference is that of degree; in real-life one is likely to be panic-stricken at the sight of a growling tiger at arms distance, but less likely so when observing such an event unfold on stage in the confines of an amphitheater.

Moreover, since a tragedy is "more alive" than a picture or any other inanimate art object — we are actually observing our fellow citizens engage in a range of activities on stage-it is reasonable to think that the emotional response of actually observing Oedipus' travails is very close to the emotional response that would be produced if one observed someone in real life undergoing similar struggles (caused by error) to that of Oedipus. Aristotle, in fact, notes that such unfixable error-induced effects are to be most feared and pitied:

And all fearful things are more fearful, in so far as, if after an error $[\dot{\alpha} \mu \dot{\alpha} \varrho \tau \omega \sigma \iota \nu]$ occurs, it is not possible to be corrected... and thus in a word, [all] things are fearful, inasmuch as, when they occur in a certain manner or when

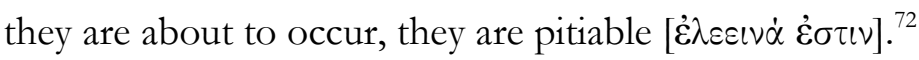

Along with pity, Aristotle goes on to address the cognitive effects that are produced and with respect to whom tragedy should befall:

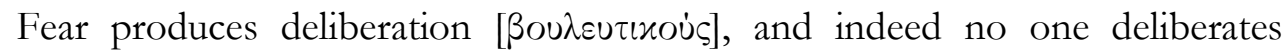
about that which is without hope. Consequently, whenever it is fitting that the audience should be afraid [that something may happen] to them, it is necessary to prepare [the audience] for such kinds of [fearful scenarios]; especially that it is possible that they will suffer such kinds [of fearful scenarios]; certainly that others have suffered greater [than they have]; and [they] are shown that those who are similar [to them] are suffering or have suffered, and have suffered at the hands of those from whom they did not expect; and both in such ways and at those times that they did not suspect. ${ }^{73}$ 
We not only fear what we think is about to happen to Oedipus as result of his honest mistakes, but we are also afraid upon reflecting how similar events could befall us. Thus, the cognitive stimulation, in conjunction with the images produced by deliberative imagination, brings to fruition a range of intensity with respect to the emotion of fear (reasonably, this would apply to pity as well). The upshot is that the emotion of fear (and pity) is imbued with cognition. Finally, Aristotle brings together the relationship of pity and suffering coupled with the relevant cognitive responses.

He tells us:

[And pity is also produced by] both signs and actions [related to suffering], for instance both the clothes of those who have painfully worked hard and as many such kinds of things, and words and all the rest of the [details] of those who are in a state of suffering, for instance those who are presently dying.

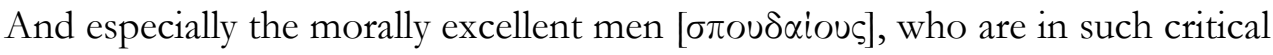
scenarios, are those who are pitiable; for all these things, on account of appearing near, produce greater pity, and both because they are undeserving of evil and because the suffering is apparent to our eyes. ${ }^{74}$

Keeping in mind the discussion of fear above, Aristotle brings together the intensity of pity by way of the confluence of events that illuminate suffering. The audience is brought to such a state of pity in the case of Oedipus in the light of his honest mistake, the undeserving events that follow, the self-inflicted wounds to his eyes, the blood on the clothing as a result of these wounds, Oedipus' own verbal and physical expressions of pain, etc. All of this comes together on stage to produce pity in the audience at a very intense level. Most notably, Aristotle points out that the cognitive dimension of pity is produced by understanding that the evil that befalls someone, like Oedipus, is undeserving, while the emotional aspect of pity is tethered to the immediacy and close distance of observing someone, like Oedipus, suffer. Thus, much like fear, pity is also imbued with cognition. Therefore, both pity and fear, according to Aristotle, are emotions that have a cognitive dimension.

Finally, unlike an actual legal trial, the judging audience can take pleasure in what has occurred to them. With the cognitive dimensions of pity and fear in place, the audience can both judge Oedipus and determine of what he is morally and legally culpable and take pleasure in the quality of such judgments. Indeed, given the role of

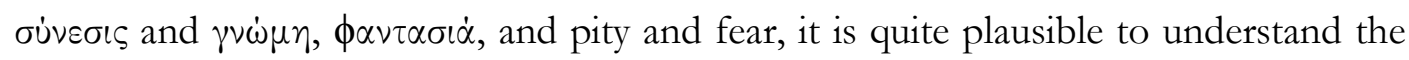


pleasure associated with Aristotle's concept of catharsis in a highly cognitive way. It is this cognitive pleasure, I argue, that captures the tragic pleasure of Aristotle's concept of catharsis.

\section{Conclusion}

By indicating the division that exists between the citizens and all others in the polis, it is possible to explicate the corresponding kinds of catharsis and tragic pleasure that are produced. Character analysis is a highly cognitive process both in everyday interactions with others as well as in observing a tragic play for the Athenian citizen. The positive account offered has revealed the plausibility of a richly cognitive interpretation of catharsis that stands in sharp contrast to Lear's anti-cognitivist interpretation. Specifically, the cathartic experience is closely linked to the evaluative judgments and rational imagination of an educated citizenry. While observing the deeds of the protagonist, the ensuing emotions of pity and fear are cognitively imbued and heightened by understanding that the framework of his predicament is, mutatis mutandis, not all that different than one that could befall most people. Additionally, as part of this experience, there is the production of tragic pleasure; namely, the joy in having judged the overall character of the protagonist correctly in the light of his overall circumstances. This interpretation, then, establishes a highly cognitive account of the cathartic experience and tragic pleasure. Indeed, it is just such an account that provides the kind of response by Aristotle that would be needed to address adequately Plato's challenge. ${ }^{75}$

\footnotetext{
${ }^{1}$ For Aristotle, to give the definition of a thing is to include, as part of the thing's essence, its function. See Meteorologica, IV.12,390a10-12. Note that there is a "teleological thread" that runs through much of Aristotle's writings. It should come as no surprise, then, that such a strand is present in his Poetics. Although this essay does not directly address the structure of "poetic teleology," see ch. 10 of Christopher Shields, Aristotle, 2nd. edn. (London: Routledge, 2014) for such an offering.

2 Please note that all translations of Aristotle's works are my own.

${ }_{3}^{3}$ Aristotle, Poetics, I.14, 1453b8-13.

${ }^{4}$ Ibid., I.14, 1453b19-23. Also see Poetics I.23, 1459a17-22 and I.25, 1461a14-b15.

${ }^{5}$ Note that Jonathan Lear's interpretation of catharsis with which this analysis takes issue is not one of these three interpretations.

6 The purgation view has been defended by Thomas Tyrwhitt, De poetica liber (E Typographeo Clarendoniano, 1794), A. S. Minturno, L'Arte Poetica (1563; Munich: Wilhelm Fink, 1971), F. L. Lucas, Tragedy in Relation to Aristotle's Poetics (London: Hogarth Press, 1953), and most rigorously by Jakob Bernays, Zwei Abhandlungen fiber die aristotelische Theorie des Drama (1857; Berlin: 1880).

${ }^{7}$ A. M. Quinton and M. Meager, "Symposium: Tragedy," Proceedings of the Aristotelian Society, suppl. vol. 34 (1960): 177.
} 
${ }^{8}$ Samuel H. Butcher, Aristotle's Theory of Poetry and Fine Art: with a critical text and translation of the Poetics (London: Macmillan, 1911), 254-55.

${ }^{9}$ Leon Golden, "Catharsis," Transactions of the American Philological Association, 93 (1962): 57.

${ }^{10}$ Despite the distinctiveness of their respective interpretations, among others, G. F. Else, Aristotle's Poetics (Cambridge: Harvard University Press, 1963), Stephen Halliwell, The Aesthetics of Mimesis (Princeton: Princeton University Press, 2002), Martha Nussbaum, "Tragedy and Self-Sufficiency: Plato and Aristotle on Fear and Pity," in Essays in Aristotle's Poetics, ed. A. O. Rorty (Princeton: Princeton University Press), 261-90, Richard Janko, "From Catharsis to the Aristotelian Mean," in Essays in Aristotle's Poetics, ed. A. O. Rorty (Princeton: Princeton University Press, 1992): 341-58, and Elizabeth Belfiore, "Pleasure, Tragedy and Aristotelian Psychology," The Classical Quarterly, 35, no. 2 (1985): 34961 broadly fit into this cognitivist camp.

11 Jonathan Lear, "Katharsis," in Essays on Aristotle's Poetics, ed. A. O. Rorty (Princeton: Princeton University Press, 1992), 315-340.

12 Ibid., 324.

${ }^{13}$ Ibid., 334 [italics mine].

14 Ibid., 323.

15 Ibid., 335.

16 There are two parts to Plato's criticism of poetry, one related to the nature of sensible objects, the other concerns the effect of poetry on the soul. First, in his account concerning the nature of art, Plato claims that the phenomenal world and its objects are not the source of true knowledge, but merely imitations $[\mu \iota \dot{\eta} \sigma \varepsilon \iota s]$ of the transcendental Forms, which we are able to grasp with our intellect alone. From this conceptual framework, Plato points out that art is three "levels" removed from the reality of the Forms. Plato makes it clear, at Republic X, 602c, that the imitations of poets to be "third from the truth." That is, an art object is merely a copy of a representation of an object in the sensible world, and the sensible world is only a copy of the World of the Forms. Thus, art is a copy of a copy of a copy (see Republic X, 598b-599a). Second, keeping this "copy of a copy of a copy" view of the nature of art in mind, in the Republic, Plato argues that poetry is harmful to the soul. Those who wish to indulge their emotions in such "wretched" activities, thinks Plato, are strengthening the lower part (i.e., the appetitive part) of their souls and thereby weakening the higher rational part of the soul. If Aristotle is to provide a convincing argument against Plato's position, he must show forcefully how poetry enhances the rational part of the soul. Indeed, this essay endeavors to make manifest that Aristotle's theory of poetry is able to address adequately Plato's challenge. For more on Plato's views regarding the effects of poetry, see M. F. Burnyeat, "Art and Mimesis in Plato's 'Republic'," The London Review of Books, May 21, 1998, 3-9, C. L. Griswold, "The Ideas and Criticism of Poetry in Plato's Republic," Journal of the History of Philosophy, 19 (1981):135-50, Stephen Halliwell, "Plato's Repudiation of the Tragic," in Tragedy and the Tragic, ed. M. S. Silk (Oxford: Clarendon Press, 1996), 332-49, Christopher Janaway, Images of Excellence: Plato's Critique of the Arts (Oxford: Clarendon Press, 1995), 106-57, Kimon Lycos, "Making Things with Words: Plato on Mimesis in Republic," Philosophical Inquiry, 18, nos. 3-4 (SummerFall, 1996): 1-19, and C. D. C. Reeve, Philosopher Kings (Princeton: Princeton University Press, 1988), 220-23.

${ }_{17}$ Aristotle, Politics, VIII.7, 1342a5-16. Lear may have this passage in mind regarding his claim that Aristotle's reply to Plato is that poetry is harmless. It is not being denied that Aristotle thinks this is so; however, this cannot be all Aristotle would want to say on the matter if he hopes to sway Plato into accepting tragic drama and other arts in the polis.

${ }^{18}$ Ibid., 1342a17-28.

${ }_{19}$ The claim is not that citizens (according to Aristotle) cannot have hedonistic cathartic experiences like those of the (b)-class - they can have both hedonistic and cognitive pleasures associated with tragedy. Given the nature of their souls, however, the (b)-class individuals can only have hedonistic cathartic experiences. This interpretation of a sort of nested hierarchy of cathartic experiences stands 
in somewhat contrast to Depew's tentative claim that the tragic effect in the Politics is not exactly the same thing as the tragic effect in the Poetics. See David Depew, "From Hymn to Tragedy: Aristotle's Genealogy of Poetic Kinds," in The Origins of Theater in Ancient Greece and Beyond: From Ritual to Drama, ed. Eric Csapo and Margaret C. Miller (Cambridge: Cambridge University Press, 2007), 126-49.

${ }^{20}$ Aristotle, Politics, VIII.5 1340a19-20.

${ }^{21}$ Aristotle, Poetics, I.6, 1450a15-24.

22 Ibid., I.13, 1452b31-1453a11. Note that 'good' here is not to suggest that Oedipus is a morally exceptional person. Aristotle makes clear that Oedipus stands between those who are highly virtuous and those who are extremely base (Poetics, I. 1453a7-12). 'Good', then, is designed to capture this intermediary position.

${ }^{23}$ Ibid., I.14, 1454a16-b8.

${ }^{24}$ Louden discusses, in addition, a third subordinate virtue, [ $\varepsilon \dot{v} \beta o u \lambda i \alpha$ ], that is much more controversial

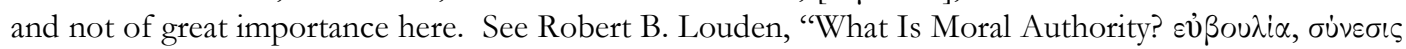

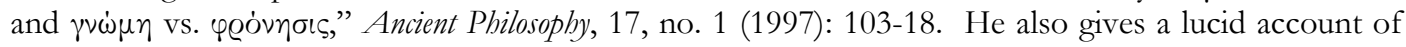
how all of these various practical intellectual virtues are related and yet distinct.

${ }^{25}$ Aristotle, Nicomachean Ethics, VI.6, 1141a3-4.

${ }^{26}$ R. Louden, "What Is Moral Authority?” 107.

27 Aristotle, Nicomachean Ethics, VI.7, 1141b15-24.

${ }^{28}$ Ibid., VI.10, 1143a8-10.

${ }^{29}$ Aristotle stresses just this point in Poetics, XIII, 1453a7-10. For further details about the nature of Aristotle's use of reversal and recognition in tragedy, see John MacFarlane, "Aristotle's Definition of 'Anagnorisis'," The American Journal of Philology, 121, no. 3 (2000): 367-83, Patchen Markell, "Tragic Recognition: Action and Identity in Antigone and Aristotle," Political Theory, 3, no. 1(2003): 6-38, Malcolm Heath, "The Best Kind of Tragic Plot: Aristotle's Arguments in Poetics 13-14," Anais De Filosofia Clássica, 2, no. 3 (2008): 1-18, and S. Halliwell, The Aesthetics of Mimesis, 220-24.

30 Aristotle, Poetics I.13, 1453a13-15. For more discussion on $\dot{\alpha} \mu \alpha \varrho \tau i \alpha$ see J. M. Bremer, Hamartia: Tragic Error in the Poetics of Aristotle and in Greek Tragedy (Amsterdam: Adolf M. Hakkert, 1968), T.C.W. Stinton, "Hamartia in Aristotle and Greek Tragedy," Classical Quarterly, 25, no. 2 (1975): 221-54, and Leon Golden "Hamartia, Ate, and Oedipus," Classical World, 72, No. 1 (1978): 3-12.

${ }^{31}$ Ibid., I.9, 1452a23-b5.

32 Janko emphasizes this didactic approach to catharsis in "From Catharsis to the Aristotelian Mean" in A.O. Rorty, ed., Essays on Aristotle's Poetics (New Jersey: Princeton University Press, 1992), pp. 341-358.

33 Aristotle, Nicomachean Ethics, IX.12, 1172a12-15. Now one might be concerned about the omission

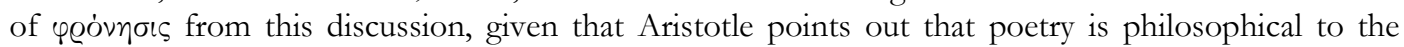
extent that it deals with events and actions that are likely to occur. This omission is intentional on the grounds that Aristotle is trying to locate the moderate philosophical sense of poetry as being more than history, but less than full-blown philosophical inquiry into ethics and action. The ability to judge the actions of others regarding how they might likely behave, how those judging could find themselves in similar circumstances, and how to judge such behaviors are the skills at hand. The argument is that the subordinate intellectual virtues are enough to actualize these skills. Thus, with respect to understanding the philosophical nature of poetry, drawing on the subordinate intellectual virtues, as opposed to

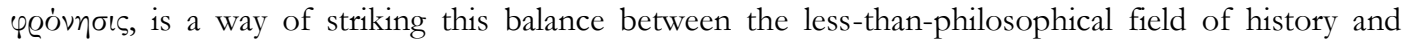
highly philosophical arena of ethics and action theory.

${ }^{34}$ Ibid., IX.11-X.1, 1171a36-1172b10.

35 Aristotle, Poetics, I.4, 1454a16-19.

36 Aristotle, Nicomachean Ethics, III.3, 1112a2-3; and III.5, 1113b3-8.

37 No doubt, the audience would also admonish Oedipus for not being a more temperate or dispassionate person $[\sigma \dot{\omega} \varphi \varrho \omega v]$ with regard to the statements made by the drunkard at the party. 
38 'for the most part' is necessary here because, according to Aristotle, one can be held blameworthy for akratic acts (weak-willed acts), which are not necessarily the product of deliberate choice; although, of course, akratic acts are not on a par with vicious acts. So, one could condemn Oedipus for being akratic, but that would likely require going beyond the details of the story. For Aristotle's discussion on akrasia, see Nicomachean Ethics, VII.1-10, 1145a15-1152a35.

${ }^{39}$ Aristotle, Poetics, I.9, 1451b9. In the production of art, Aristotle notes the importance of extracting the universal from particular experiences: "And art [ $\tau \dot{\varepsilon} \chi \nu \eta]$ comes to be whenever from many reflections upon experience a single universal [ $\kappa \alpha \theta \dot{0} \lambda \mathrm{O}$ ] [judgment] is produced in relation to similar objects." Given the high level of education possessed by the citizens, it is reasonable to think that they can discern the universals associated with the particulars of a drama that are in keeping with the universals discerned and employed by a poet. The position taken here is that this extraction can occur

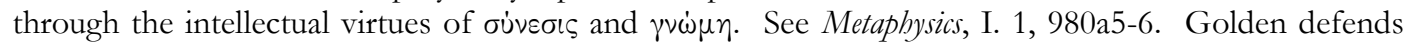
what he calls an "intellectual clarification" account of catharsis based on this ability to extract the universals embedded in the particulars of a tragic play. See L. Golden, Aristotle on Tragic and Comic Mimesis (Atlanta: Scholars Press, 1992), 5-39.

40 Aristotle, Politics, III.5, 1278a8-13. Although this quotation does not come from Aristotle's discussion of the ideal city-state, it could be viewed as how he might envision an ideal citizen body that is free of labor.

${ }^{41}$ See Aristotle's Poetics: Translated with a Commentary by George Walley, ed. John Baxter and Patrick Atherton (Montreal: McGill-Queen's University Press, 1997), xxv.

${ }^{42}$ As Aristotle points out at Metaphysics, V.29 1024b24-26, "Things are called false either because they themselves are not or because the phantasia that results from them is of what is not"(italics mine). Note, as far as I can tell, Caston is one of the few recent commentators who is sensitive to keep this problem of error as the central theme of De Anima, III.3. See Victor Caston, "Why Aristotle Needs

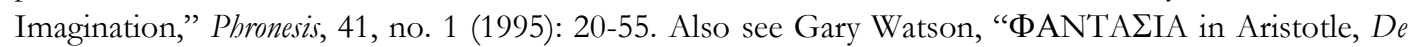
Anima 3.3," Classical Quarterly, 32, no. 1 (1982): 100-13 and Ronald Polansky, Aristotle's De Anima (Cambridge: Cambridge University Press, 2007) for similar accounts.

${ }^{43}$ Aristotle, De Anima, III.3 433b29-434a7.

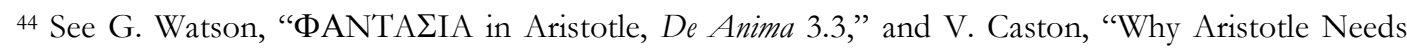
Imagination."

${ }^{45}$ See Dorothea Frede, "The Cognitive Role of Phantasia in Aristotle," in Essays on Aristotle's De Anima, ed. Martha C. Nussbaum and Amelie Oksenberg Rorty (Oxford: Clarendon Press, 1992), 288-89 and S. Pendlebury, "Practical Arguments, Rationalization and Imagination in Teachers' Practical Reasoning: A Critical Discussion," Journal of Curriculum Studies, 25, no. 1 (1993):147.

${ }^{46}$ Aristotle, De Motu Animalium, I.6, 700b17-22.

47 Aristotle, De Anima, III.11, 434a5-10.

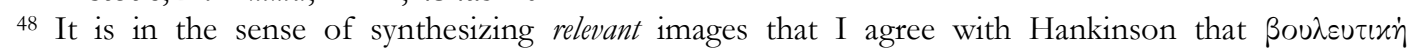
$\varphi \alpha \nu \tau \alpha \sigma i \dot{\alpha}$, as distinct from $\alpha \grave{\sigma} \sigma \theta \eta \sigma \iota \varsigma$ and $\dot{v} \pi \dot{\partial} \lambda \eta \psi \iota \varsigma$, engages in the activity of comparison. As Hankinson

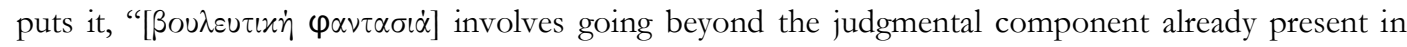
perception, although not as far as that which corresponds to propositional judgment properly so-called, hupolêpsis." See R. J. Hankinson, "Perception and Evaluation: Aristotle on the Moral Imagination," Dialogue, vol. 39 (1990): 52.

49 Aristotle, De Anima, III.7, 431b2-8.

50 Ibid., III. 10, 433b10-13.

${ }^{51}$ J. A. Smith's translation of Aristotle's De Anima, III.10, 433b10-13, in The Complete Works of Aristotle, vol. 1, ed. Jonathan Barnes (New Jersey: Princeton University Press, 1985), 689.

52 Aristotle, Rhetoric II.5, 1383a15-19.

53 Aristotle, De Memoria I, 450b21-27. 


\begin{abstract}
54 Aristotle, Poetics IV, 1448b12-13. 'this [person] is that [person]' follows Halliwell's translation. See S. Halliwell, The Aesthetics of Mimesis, p. 178, n. 3.

55 Ibid., IV, 1448 b13.

56 Aristotle, Parts of Animals, I.1, 639a1-9) [italics mine].

${ }^{57}$ E. Belfiore, "Pleasure, Tragedy and Aristotelian Psychology," 359-60. I have slightly re-arranged some of the sentences for the sake of conciseness. This discussion relies upon Aristotle, Rhetoric II.5 1383a5-8, 2.81386a7-9 and 1386a21.

58 Puttfarken hints at this same kind of judgment: "We pity the person who does not deserve his fate, while horror or fear overcomes us when we are faced with something similar to ourselves." See Thomas Puttfarken, "Aristotle, Titian, and Tragic Painting," in Art and Thought, ed. Dana Arnold and Margaret Iversen (Oxford: Blackwell, 2003), 17. Moreover, this account of pity is in keeping with Halliwell's insightful analysis of pity in which the spectator of a play can empathize with the plight of the protagonist, but cannot actually "share the sufferer's subjectivity: however much we may draw emotionally near to it, or move vicariously with its psychological expression, we remain, qua feelers or pity, outside the immediate, 'first-person' reality of the pain, whether physical or mental." I could not agree more with Halliwell's analysis here. In fact, it is because our empathetic response cannot access first-person subjectivity that we are able to reflect on the possibility of our own personal predicaments being similar to that of the protagonist. See S. Halliwell, The Aesthetics of Mimesis, 216.
\end{abstract}

59 Aristotle, Rhetoric, II. 8, 1386a28-34.

${ }^{60} \mathrm{I}$ am here clearly referring to the pleasure had by the educated citizenry.

${ }^{61}$ At Rhetoric II. 6, 1385b38-40, Aristotle does point out that being panic-stricken makes it nearly impossible to be able to express pity because one is consumed by one's own fear. So, although it is reasonable to think that the audience of a tragedy may express much fear as the plot unfolds, it is unlikely that they would be panic-stricken or should be induced to be panic-stricken given the need to express pity or compassion.

${ }^{62}$ Ibid., II.5,1382a21-22.

${ }_{63}$ Aristotle, De Anima, III.3, 427b21-24.

${ }^{64}$ For further details, see William. W. Fortentbaugh, Aristotle on Emotion (New York: Harper and Row Publishers, 1975).

${ }^{65}$ See S. Halliwell's The Aesthetics of Mimesis. Similarly, Else argues that the proper pleasure of tragedy includes both an intellectual component and an emotional one. See chapter 11 of Gerald F. Else, Plato and Aristotle on Poetry (Chapel Hill: University of North Carolina Press, 1987). Else also embraces a "jury-like" view of the spectator at a play and gives ample weight to the connection between pity and judgment: "But under what circumstances can I bring myself to pity the murderer or would-be murderer? I can pity him if I judge that he did not intend the parricide, matricide, or whatever, as such: in other

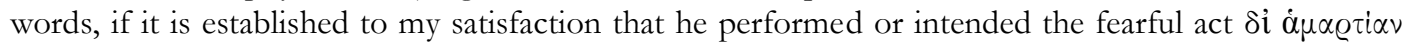
$\tau \iota \dot{\alpha}$, because of some error." See Gerald F. Else, Aristotle's Poetics (Cambridge: Harvard University Press, 1963), p. 437.

${ }^{66}$ S. Halliwell's The Aesthetics of Mimesis, p. 206.

${ }^{67} \mathrm{~W}$. W. Fortenbaugh addresses dramatic poetry. He says: "Aristotle adopted an inclusive view of emotional response. He recognized both its cognitive and its bodily aspects. This meant that Aristotle could not only reject the Platonic suggestion that dramatic poetry plays to unintelligent feelings divorced from reason but also meet the Platonic demand for a positive benefit to human life (Rep. 607d8-9)." See W. W. Fortenbaugh, Aristotle on Emotion, 21.

68 S. Halliwell, The Aesthetics of Mimesis, 205

${ }^{69}$ Ibid., 204-5

70 Notably, Halliwell concedes on this same page that Aristotle does not pursue the possibility of tragedy producing this kind of response. Again, my account of rational imagination as it pertains to the cathartic experience reveals that this sort of response is not at all hostile to Aristotle's thinking. 


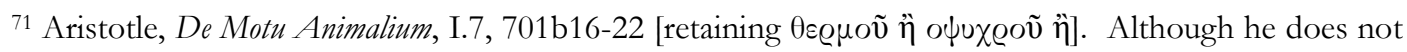
us the language of imagination, it is clearly implied when Aristotle makes the following point about pity: "And, indeed, on the whole, [a man experiences pity] in this manner whenever he is in a state of remembering that such kinds [of undeserving tribulations] have happened or are expected to happen to himself or to those [family and friends] of his." Aristotle, Rhetoric, II.8, 1386a1-3. Again, the faculty of imagination must be at work in order for there to be images that are remembered and upon which are reflected.

${ }^{72}$ Aristotle, Rhetoric, II. 5, 1382b23-27.

${ }^{73}$ Ibid., II. 5, 1383a7-12.

${ }^{74}$ Ibid., II. 8, 1386b2-7 (italics mine).

${ }^{75}$ Earlier versions of this paper were presented at Bowling Green State University, California State University Fullerton, Chicago State University, University of Kentucky, and The Society for Ancient Greek Philosophy. I am grateful to all the participants at these venues for their helpful comments. Moreover, I would like to thank Marv Belzer, Jim Child, Ben Dixon, Paul Gomberg, Robert Grant, Ralph Hanke, Carrie-Ann Biondi, Louise Collins, Loren Lomasky, Phillip Peek, Christopher Perricone, Christopher Shields, and James Taylor for discussing and/or reviewing early versions of this paper. Their critical feedback was invaluable. Additionally, I must acknowledge the research and financial support of the College of Liberal Arts \& Sciences at IU South Bend-particularly the efforts of Elizabeth Dunn (Dean of the College of Liberal Arts \& Sciences) and her staff. Finally, I would like to express a special thanks to David Depew and Fred D. Miller, Jr. ; the former for introdcuing me to Aristotle's theory of art many moons ago and the latter for taking the time to read multiple versions of this paper, offering detailed comments, and providing much encouragement. Of course, the above individuals do not necessarily share my interpretations and conclusions. 